\title{
TÜRK VE RUS KAYNAKLARI IŞIĞINDA 1989 FERGANA OLAYLARI
}

\author{
1989 FERGANA EVENTS IN THE LIGHT OF TURKISH AND RUSSIAN \\ SOURCES
}

\section{Khalida DEVRISHEVA*}

DEVRISHEVA, Khalida, (2019), "Türk ve Rus Kaynakları Işığında 1989 Fergana Olayları", Belgi Dergisi, C.2, S.17, Pamukkale Üniversitesi Atatürk İlkeleri ve İnkılâp Tarihi Araştırma ve Uygulama Merkezi Yayınları, Kış 2019/I, ss. 1170-1187.

Öz

Sovyetler Birliği yönetimindeki birçok halk, özellikle Türk soylular, siyasi baskıya uğrayarak vatanlarından sürülmüşlerdi. Bugüne kadar vatanına geri dönemeyen Türk topluluklarından biri de Ahıska Türkleridir. Gürcistan'ın yerli halkı olan Ahıskalılar, ülkenin güneyindeki Akhiska (Meshetia), Ahaltsike, Adigön, Aspindza ve kısmen Javaheti (Ahılkelek bölgesi)'nin üç bölgesinde asırlar boyu varlıklarını sürdürmüşlerdi. 1944 yılında, Sovyetler tarafindan tarihi anavatanlarından Orta Asya Cumhuriyetlerine sürgün edilmişler, ancak orada da huzur bulamamışlardı. 1989 yılında Ahıska sakinleri Özbekistan SSC'in Fergana bölgesinde "Fergana Olayları" olarak bilinen kitlesel çaţ̧̧malar sonucunda, toplu bir faciaya maruz bırakıldılar. Bu olaylar sırasında Ahıska Türkleri büyük zararlar gördüler. Dünya kamuoyu ilk kez Ahıska Türklerini "Turki Meshetintsı" olarak bu kanlı olaydan sonra tanıdı. Rus basınında "Fergana Olayları" diye geçen bu elim olayın ardından, Rus hükümeti Fergana ve yakın bölgelerden Ahıska Türklerini organize bir şekilde SSCB'nin farklı cumhuriyetlerine gönderdi. Özbekistan'ın neredeyse tüm bölgelerinde yaşayan Türk nüfusu diğer Sovyet cumhuriyetlerine göç etmeye mecbur kaldılar. Fergana olaylarına daha yakından bakıldığında, bilinen "çatışma" kavramının çok ötesinde olduğunu görmekteyiz. Bu nedenle, çalışmamızda Ahıskalılar başına gelen bu acı olayı, Rus basını ışı̆̆ında araştırmaya ve değerlendirmeye çalışacağız.

Anahtar Kelimeler: Ahıska, Ahıska Türkleri, Fergana, Sürgün, Sovyet Rusya, Özbekistan

\begin{abstract}
During the Soviet era, many communities, especially Turkish origins, were exiled from their homeland under political pressure. One of these Turkish communities that cannot return to their homeland until today is the Meskhetian Turks. Meskhetians, the indigenous people of Georgia, have lived in the three regions of Akhiska (Meshetia), Ahaltsike, Adigon, Aspindza and partially Javaheti (Ahilkelek region) in the south of the country. In 1944, they were exiled by the Soviets from their historical homeland to the Central Asian Republics, but they could not find peace there. In 1989, the inhabitants of Ahiska were subjected to a mass catastrophe as a result of mass clashes known as the "Ferghana Events" in the Ferghana region of the Uzbek SSR. During these events, the Meskhetian Turks suffered great damage. For the first time, the world public opinion recognized the Ahiska Turks as " Meskhetians"after this bloody incident. After this deplorable incident in the Russian press, Russian government sent the Meskhetian Turks from Ferghana and nearby regions to the different republics of the USSR. The Turkish populations living in almost all regions of Uzbekistan were forced to migrate to other Soviet republics. When we focus on the Ferghana events, we see that it is far beyond the known concept of conflict. Therefore, in this paper, we will try to investigate and evaluate this suffering event that happened to the Mesketians in the light of the Russian press.
\end{abstract}

Keywords: Ahıska, Meskhetian Turks, Ferghana, Deportation, Soviet Russia, Uzbekistan

*Dr. Öğ. Üyesi, Pamukkale Üniversitesi, Fen-Edebiyat Fakültesi Tarih Bölümü, Genel Türk Tarihi ABD, Denizli: kdevrisheva@pau.edu.tr, (orcid.org/0000-0001-6474-8788). 


\section{Giriş}

Makalenin yazıldığı 2018 yılı itibariyle, Ahıska Türklerinin sürgünlerinin 74. yılında, geçmişe baktığımızda, onların bu zaman zarfında 3 kez daha sürgüne ${ }^{1}$ uğradıkları görülmektedir. İlki, 1944 yılında Stalin liderliğindeki SSCB, Ahıska bölgesinde asırlarca 212 köyde yaşayan Ahıska Türklerini ${ }^{2}$, "sınır güvenliğini tehdit etmekle" suçlayarak, anavatan topraklarından sürgün etmişlerdi ${ }^{3}$. Sovyetler Cumhuriyetlerine getirilip dağıtılan Ahıskalıların bir kısmı Özbekistan'a gönderilmişti. Burada, Fergana, Sırderya, Semerkant ve Margelan gibi bölgelere dağıtılmışlardı. 1956 yılına kadar sıkı rejimde yaşayan Türkler sürgün edildikleri yerlerden hiç kıpırdayamamışlardı. Stalin'in vefatı ile Türkler için durum az da olsa değişmişti. Zaman geçtikçe, Ahıskalılar Özbekistan'ı ikinci vatan olarak görmüş ve benimsemişlerdi. Ayrıca, Özbek kardeşleri ile yıllarca barış ve huzur içinde yan yana yaşamışlardı.

1944 yılı sürgününden sonra başlarına gelen ikinci acı olay 1989 yılında Özbekistan'da Fergana bölgesinde yaşanmıştı. Bölgede Özbek ve Ahıska Türkleri arasında meydana gelen etnik trajediden tam 30 yıl geçmiştir. 1989 yılından günümüze dek, Özbekistan'da Fergana bölgesinde Ahıska Türklerinin yaşadıkları "Fergana Olayları” dünya kamuoyunda, birçok eser, makale yazılmış ve çeşitli fikirler öne sürülmüştür ${ }^{4}$. Ancak, birçok Türk, Rus ve yabancı basın mensupları bu konuda hemfikirdi. Fergana olayları ile ilgili onlara sunulan ve ortaya atılan farklı versiyonlar, durumu açığa kavuşturmak için ikna edici değildi ${ }^{5}$. Gerçekleşen olaylara yüzeysel baktığımızda bile, açıkça yalnızca şunu görmekteyiz ki, bu vaka ve çatışmalarda mağdur olan tek taraf vardı, o da Ahıska Türkleriydi. Saldırganlar hakkında ise net bir şey söylenmemişti. O kişiler kimlerdi, amaçları neydi, Ahıskalılardan ne istemişlerdi ve kimin tarafından yönetilmişlerdi.

Fergana bölgesindeki olayları ışığa kavuşturmak ve sağlıklı bilgiye ulaşmak için Özbekistan ve Rusya Milli Arşivlerine başvuru yapsak da, aradan uzun zamanın geçmesi ile Sovyet Birliği dağıldıktan sonra, devlet kurumların birçoğunda bazı belge ve doküman üzerine getirilen gizlilik uygulaması buna mani olmaktadır. Bu sebeple, bu olayda yer alanların ve gözlemcilerin görüşlerine dayanarak olaylar hakkındaki bazı gerçekleri ortaya koymaya çalışacağız. Şimdiye kadar, Ahıska Türklerinin sürgünü ve Fergana'da yaşadıkları hakkında daha çok Türk basını tarafından bilgi verilmiştir. Ayrıca sayısı fazla olmasa da,

1 “Deportatsiya" terimi, Latince "deportatio" - "sürgün”, "sınır dışı etme”, "kovulma” anlamına gelmektedir. Süreli, bazen de bilimsel yayınlarda, bu terim Ruslar tarafından ortaya çıkarılmış diye bilinmektedir. Bu konuda hemfikir olmak zordur, çünkü Orta Çağlarda bile, İngiltere'den Çingeneler, Fransa'dan Araplar ve Yahudiler sürgün edilmişti. 1924 yılında Yunanistan ve Bulgaristan'dan Türkler sınır dışı edilmişti. 1942 yılında, Amerika Birleşik Devletlerinin 32. başkanı F. Roosevelt, Japon asıllı 120 bin kişiyi batı eyaletlerinden diğer eyaletlere göndermiş ve özel korumalı kamplara yerleştirmişti. Ancak, tarihin gerçeği şu ki, SSCB'nin liderleri, önceki deneyimlere dayanarak "yaratıcı bir şekilde" sürgün terimini, devlet ulusal politikasının rütbesine yükseltmişlerdi. XX. yüzyılın 1930-50 yılları boyunca, 1 milyon 8 binden fazla insanı siyasi, sosyal ve etnik suç yükleyerek sürgün etmişlerdi. Bunların 100 bini de Ahıska Türküydü. Bkz. Yuriy Gulbinskiy, Naçalnıy Period Velikoy Oteçestvennoy Voynı i Deportatsiya Rossiyskih Nemtsev: Vzglyadı i Otsenki Çerez 70 let, Materialı 3-ey Mejduanrodnoy NauçnoPraktiçeskoy Konferentsii, Saratov, 26-28 Avgust-2011, Moskva, 2011, s. 461.

2 Eduard Paneş, Leonid Yermolov, "Turki Meshetintsı (İstorikoEtnografiçeskiy Analiz Problemı)", Sovetskaya Etnografiya, № 1, Moskva, 1990, s. 16.

3 Aleksandr Osipov, "Dvijeniye Meshetintsev za Repatriatsiyu (1956-1988)", Etnografiçeskoye Obozreniye, № 5, 1998, s. 95; Aleksandr Yakovlev, Stalinskiye Deportatsii. 1928-1953, (Rossiya. XX. vek. Dokumentı), İzd. "Materik", Moskva, 2005, s. 525-526.

4 Viktoriya Simonenko, Meshetinskiye Turki: İstoriçeskaya Sudba i Problemı Kulturnoy Adaptasii, Krasnodar, 2002, s 13.

5 Orkhan Faigov, Ahıskalı Türklerin Türk Basınında Sunum Biçimi 1944 Ahıska Sürgünü, 1989 Fergana Faciası, 2004 Krosnodar Göçü ve 2010 Kırgızistan Çatışması Örnek Olayları, (Basılmamış Yüksek Lisans Tezi Erzurum), 2015, s. 57-60. 
bazı Rus bilim adamları da bu konu ile ilgilenmekte ve bazı çalışmalar yapmaktadırlar. Bu çalışmalardan yola çıkarak, Ahıska Türklerinin başına gelen ve "Fergana Olayları" adıyla bilinen bu vakanın aslında basit bir mahalle kavgası değil, büyük bir etnik çatışma olduğunu görmekteyiz. Olaylara karışan insanların başına gelenler ile bunlara vermiş oldukları tepkilerin neler olduğunu anlatmaya çalışacağız.

\section{AHISKA YURDU VE AHISKA'NIN ANLAMI}

Meskhet/Meshetya, Güney Gürcistan'da (Ahalsikhe (Ahıska) ülkesi diye de bilinen, Tiflis'in 150 km. batısında, Türkiye'nin Kuzey Doğusunda, Ardahan Illimizle sınır olan dağlık bir bölgedir. Bu bölge Kuzeyde Borjoma, Güneyde Çıldır düzlüğüne, Doğuda Borçalı’ya, Batıda Acar topraklarına dayanır. Ahıska, Adigön, Aspinza, Ahılkelek ve Bogdanovka gibi önemli yerleşim birimleri ile 220'den fazla köyün merkezi olan Ahıska şehrinin yüz ölçümü 6260 km² büyüklüğündedir. Bu topraklar tarıma ve hayvancılığa çok elverişlidir. Bu bölge, Gürcistan'da; "Meskhet Dahavacheti” olarak anılmaktadır. Orada yaşamış Türklere de "Meskhet Türkleri" denilir. Ancak doğrusu, "Ahıska Türkleri”dir6.

Ahıska kelimesinin anlamı ile ilgili birçok fikir bulunmaktadır. Bunlardan biri Ak Kale anlamına gelen "Ak - Sıka” sözüdür. Oğuzların tarihi yurdu olan Ahıska'nın 481 yılına ait kaynaklarda "Akesga" olarak geçtiği görülmektedir. Gürcüce bu bölgenin adının manasına dikkat ettiğimizde "AkhalTsikhe" kelimesi ile karşılık bulduğu anlaşılmaktadır. "Akhali" Gürcüce yeni, "Tsikhe" ise kale anlamında kullanılmaktadır?.

Bununla beraber, Ahıska kelimesi, Gürcüce; “Yeni-Kale” anlamına gelen Ahal-Tsihe'nin Türkçe ve Farsça şeklidir. Ayrıca, Ahıska, Dede Korkut kitabındaki "Ak-Sıka” kelimesiyle ilişkili olup "Ak-Kala" manasına gelmektedir. Ahıska kelimesini Ahıska bölgesinin dört tarafında bulunan kavimler, kendi dillerinde şöyle söylerler. Bu meyanda, Ahıska, AkhırKıska, Akhal-Kelek, Ak-Sıka gibi kelimeler kullanılır. Bugün Gürcüler, "Yeni-Kale" manasına gelen "Akhal-Tsikhe" diye bunun kendi dillerinden olduğunu iddia ederler". Ancak, bölge hakkında bilgi veren birçok kaynak, "Ahıska" adının doğrudan "Ak-şehir" manasına geldiğini belirt etmektedir.

\section{AHISKA TÜRKLERININ TARIHI}

Anadolu'da Kür ve Aras ırmakları ile Hazar Denizi'ne akan kesiminde bulunan ÇıldırAhıska Eyaleti, M.Ö. 680 yıllarında Saka (İskit) boylarının yerleşmesinden beri en eski Türklük bölgesidir ${ }^{9}$. Milattan sonra X. yüzyılına kadarki dönemlerde ise bölgede, Hazar, Urartu ve Arap hâkimiyeti görülmüştür. X. yüzyıldan sonraki bin yıllık dönemi birkaç tarihi döneme ayrılabilir. Bunların ilki, eski yerlilere ilaveten güneyden Oğuz ve Kuzeyden gelen Kıpçak Türklerinin bölgede iskân dönemidir. Sultan Alp Arslan'ın 1068 seferiyle alınan Ahıska Bölgesi, onun ölümünden sonra Bizans'ın yardımlarıyla Gürcistan'a geçmişti. Modern tarihlerde yer alan bilgilere göre, onun oğlu Selçuklu Sultanı Melikşah zamanında buralar yeniden Türklerin hâkimiyetine girmiş, Ahıska, Ardahan, Oltu, Artvin, Batum'a kadar olan bu geniş arazi Müslüman Oğuz Türklerinin iskânına geçmiştir.

Zamanla ülkede nüfuz sahibi olan Kıpçaklar ordu, maliye ve devlet yönetiminde birinci derecede söz sahibi olmuşlardı. Aynı dönem Kıpçaklar arasında öne çıkan ünlü ailelerden biri Atabeklerdi. Zamanla daha da güçlenerek, 1268 yılında Ahıska'da bir Atabek Hükümeti 6 İbrahim Agara, İnsanlık Dramı, İzmir, 2004, s.3.

7 Orkhan Faigov, a.g.t., 2015, s. 37.

8 Fahrettin Kırzıoğlu, Dede-Korkut Oğuznameleri, 1. Kitap, İstanbul, 1952, s. 64-65.

9 Feridun Ababay, Çıldır Tarihi, Ankara, 1987, s. 14-65. 
kurulmuş ve bu dönemde ciddi nüfuz sahibi olmuşlardı. 1453 yılında İstanbul'un Türkler tarafından fethedilmesi ile 1462'de bölgeye Akkoyunlu Hükümdarı Uzun Hasan gelerek Atabeklere destek vermişti. 1578 yılında ise, Lala Mustafa Paşa Şark Seferine çıkarak Safevileri yenmiş, Posof, Vale, Ahıska, Azgur, Tümük ve Ahılkeleğ’i ele geçirmişti. Yeni fethedilen yerlerde yeni eyaletler kuruldu. Safevilere karşı kazanılan zafer yerinin adıyla burada kurulan eyalete Çıldır Eyaleti adı verildi. Bu eyaletin merkezi de Ahıska şehri oldu. 1595 yılında bölgenin tahriri yapıldı ve defteri hazırlandı ${ }^{10}$.

Çıldır Eyaleti'nin merkezi Ahıska şehri canlandı, bir ilim ve ticaret merkezi haline geldi. Ahıska medreselerinde yetişen bilginlerin Erzurum'a ve İstanbul'a gittiğini, buralardan yetişen birçok ünlü bilgin, asker ve devlet adamının olduğunu biliyoruz. Ne yazık ki, Ahıska'nın Osmanlı Dönemi 250 sene sürmüştür. Deli Petro'dan beri dünyanın köprüsü Kafkasya ile buranın üzerinden Akdeniz'e ulaşmayı gözüne kestirmiş olan Rus siyaseti, 1828 yılında vukua gelen Osmanlı-Rus harbi sonrası bu memleketi Osmanlı'dan koparmıştı ${ }^{11}$. Rumeli ve Kafkas cephelerinde yapılan savaşların en kanlısı herhalde 1828 harbidir. Rus askeri kaynaklarının da tanıklık ettiği gibi, Ahıska halkı bu savaşta, yediden yetmişe yurdunu savunmuş ve destani kahramanlıklar göstermiştir. 1829 yılında imzalanan Edirne Antlaşması ${ }^{12}$ ile Ahıska bölgesi tahliye edilerek Ruslara bırakılmıştı ${ }^{13}$.

Rus İmparatorluğuna geçen bu bölgeye yeni idare sistemi getirilmişti. Ahıska bir kaza halinde Tiflis vilayetine bağlandı. Çarlık döneminde bölgede etnik temizleme yapıldı diyebiliriz. 1828 Harbi ile bölgeye Ermeniler getirilip yerleştirildi. Böylece Ahıska merkezi ve çevresi neredeyse tamamen Ermeniler ile dolmuştu. Günden güne bölgede artan Ermeni nüfusu, buradan Türk ahalinin göçünü hızlandırdı. 1917 yılına kadar Ahıska'da bulunan kaliteli insan zümresi Anadolu'ya göç etmiş, geride hali yerinde olmayan ve göçü göze alamayan çaresizler kalmıştı. Eğitimi yalnızca medreselerde alan Türklerin, durumu zamanla daha da vahim olmuştu. 1917 yılında Kafkaslarda 90 yıllık Çarlık rejimi sona erir, bölgede Bolşevik devri başlamıştı. 3 Mart 1918'de Brest-Litovsk Antlaşması imzalanmış, 1878 'de Osmanlı'dan koparılmış olan Kars, Ardahan ve Batum iade edilmişti ${ }^{14}$. Bu iller ve Ahıska yeniden vatanlarına katmıştı. Bu antlaşma Ahıskalılar için büyük sevinç sebebi olmuş ancak sevinçleri çok fazla sürmemişti. 30 Ekim 1918 tarihinde imzalanan Mondros Mütarekesi'yle Türk ordusu Sarıkamış hududuna çekilir ve günümüze dek o topraklar önce Rus sonra ise Gürcistan sınırı içerisinde kalacaktır. Bu gelişmeler Türk ahalisini çok etkilemiş, bölgede onlara karşı zulüm ve şiddet artmıştı. Ayrıca 16 Mart 1921 tarihinde imzalanan Moskova Antlaşması ile Batum merkezi Acara ve Ahıska bölgesi Gürcistan'a terk edilmişti. Aynı yılın 13 Ekim ayında imzalanan Kars Antlaşması'nda bu sınırlar teyit edildi ${ }^{15}$.

Çarlık Rusya'sının yerine gelen Bolşevikler Sovyetler Birliğini kurmuşlardı. Bolşeviklerin gelmesi ile Ahıska Türklerinin üzerindeki baskı ve zulüm azalmamış, daha da artmıştı. 1828 yılından itibaren, yüz seneye yakın bu bölge sürekli savaşlara tanık olmuştu. Türk ahalisinin yarısı bölgeyi terk edip Türkiye'ye göç etmiştir, geride kalanlar ise, yeni iktidara uyum sağlamaya çalışmakla hayatına devam etmişlerdi. Ancak bölgedeki eski günlerin neşesi

10 Yunus Zeyrek, Dünden Bugüne Ahıska Türklüğü, Türk Federasyon Yayınları, Frankfurt, 1995, s. 32-50.

11 Yunus Zeyrek, Ahıska Gül İdi Gitti, Ankara, 2015, s. 13-14.

12 Polnoye Sobraniye Zakonov Rossiyskoy Imperii, Sobraniye 2-e, T. 4, №3128, SPb, 183; Vitaliy Şeremetov, Turtsiya i Andrianopolskiy Mir, izdatelstvo "Nauka”, 1975.

13 Asiyet Aşhamahova, Yujnaya Gruziya pod Upravleniyem Rossiyskoy Imperii, s. 2.

14 Ali Arslan, “I. Dünya Savaşı ve Milli Mücadele Döneminde Ahıska-Ahılkelek (1914-1921)”, Kafkas Araştırmaları Dergisi, N3, İstanbul, 1997, s. 99.

15 Ibrahim Agara, a.g.e., 2004, s. 11-24. 
ve huzurundan eser bile kalmamıştı. Maddi olarak sıkıntı içindeki Türklerin malları alınıp Sovyetlerin kurdukları kolhozlara devredilmişti. 1930 senesinde Bolşevik iktidarına gelen yeni lider Stalin bölgenin durumunu beter hale sokmuştu. ileri gelenler ve az çok okuma yazmayı bilen, durumu kavrayan birçok Türk aydını kurşuna dizilir, kimi de Sibirya'ya sürgüne gönderilir. Şanslı olanlar aileleri beraber gizlice sınırı geçerek Türkiye'ye sığınır ${ }^{16}$.

1941 yılında başlayan II. Dünya Savaşı ile evvel hiçbir şekilde orduya alınmayan Ahıska Türklerinin, bu sefer silah tutabilen tüm erkeklerini Alman cephesine göndermişlerdi ${ }^{17}$. Geride kalan gelin, kız, çocuk ve yaşılların eline kazma kürek verilerek Borcom-Ahıska arasında demiryolu hattı yapılması için göndermişlerdi. Oysa bu demiryolu hattının bitimi ile bölgenin halkı buraya gelen trenlerle sürgün damgasını alarak uzun ve dönüşü olmayan bir yolculuğa çıkacaklardı. Sovyet Partisinin Birinci sekreteri Josef Stalin ve İç İ̧̧leri bakanı Lavrentiy Beriya ikisi de Gürcü'ydü. Bölgeyi Ahıskalılardan temizlemek planını Lavrentiy Beriya hazırlamış, Stalin ise bu planı onaylamıştı. 31 Temmuz 1944 tarihinde Stalin'in imzaladığı kararla Ahıska ve çevresi, yani 220 köy ve bölgede yaşayan tüm Türkler buradan sürülecekti ${ }^{18}$. Hazırlıklar için yalnızca birkaç saat verilmişti. Türklerle beraber Acaralı Laz ve Hemşinler de bölgeden sürgün edilmişti ${ }^{19}$.

Sürgün gerçekleştirdikten sonra İçişleri Komiseri Lavrentiy Beriya'nın Stalin'e verdiği raporunda, bölgede uygulanan sürgün planı başarı ile tamamlandığını beyan etmekteydi. Sürgün edilen Ahıskalılar ise, arkalarında ev barklarını, mal mülklerini ve en önemlisi dedelerinin onlara emanet ettiği toprakları bırakmışlardı. Özellikle kış mevsimine yakın dönemde planlanmış sürgün esnasında, soğuk hayvan vagonlarında insaniyet dışı şartlarda, yarı aç şekilde gerçekleşen bu ölümcül yolculukta, 80 bin Ahıska Türkü içinden 20 bine yakını hayatını kaybetmişti. Ölenler arasında ilk sırada, çocuk, hamile ve yaşlı insanlar yer almıştı. Rus askerleri vagonları dolaşarak, donmuş bedenleri toplayıp dışarı atıyorlardı. Bu nedenle vefat edenin yakınları naaşlarını gizleyip, nadiren duran trenden indirip, dinlerine uygun bir şekilde gömmüşlerdi.

Bir aya yakın süren bu zor yolculuk üç hafta sonra bitmişti. Ahıskalılar daha evvel bilmedikleri Orta Asya'ya getirilmişti. Burada, Kazakistan, Özbekistan ve Kırgızistan'a önceden belirlenmiş köylere dağınık bir şekilde yerleştirildiler ${ }^{20}$. Geldikleri yeni topraklarda büyük zorluklarla karşılaşan Ahıskalılar, açlık, soğuk ve belirsizlik içinde yeni şartlara ayak uydurmak zorunda kalmışlardı. Yerli halkın dilini bilmeden, büyük aileleri küçücük topraktan yapılmış eski evlerde dağınık ve perişan bir halde hayata tutunmayı başarmışlardı. Ahıska Türkleri sürgün oldukları zaman, Almanlara karşı cephede savaşan 40 bin Türkün yarısı geri dönmedi. Dönenler ise evlerinde yabancıları görüp, Orta Asya'ya ailelerini aramak için yola çıkmışlardı. Ancak birçoğu ailesine kavuşamadı, zor yollarda kaybolup tarihe karıştılar ${ }^{21}$.

1953 yılında Sovyetlerin lideri Stalin vefat eder ve ülke az da olsa rahata kavuşur. 31 Ekim 1956 tarihinde Komünist Partisi Kongresinde, Yüksek Sovyetlerin kararı ile Ahıskalılar sıkı rejim kontrolünden kurtulur. Ülke sınırları içerisinde göç etme ve dolaşma serbestliği getirilerek, birbirini kaybeden aileler yıllar sonra bir araya gelir. Ayrıca, Stalin döneminde

16 Rasim Bayraktar, Ahıska-çıldır Beylerbeyliği, Yaşayan Kitaplar, İstanbul, 2000, s. 60-93.

17 Aleksey Bezugolnıy, Nikolay Bugay, Krinko Yevgeniy, Gortsı Severnogo Kavkaza v Velikoy Oteçestvennoy Voyne 1941-1945. Problemı İstorii, İstoriografii i Istoçnikovedeniya, İzd. Tsentpoligraf, 2012, s. 15-19; Nikolay Bugay, L. Beriya-I. Stalinu "Soglassno Vaşemu Ukazaniyu", Moskva, 1994, s. 14.

18 Svetlana Akkiyeva, Turki Meshetintsı v KBR: Demografiçeskoye i Etnokulturnoye Razvitiye, Nalçik, 2016, s. 17. 19 Pavel Polyan, "Nasistvennıye Migratsii i Geografiya Naseleniya", Mir Rossii, № 4, 1999, s. 107.

20 Asif Hacılı, Aydın Polatoğu, Ahıska Türk Folkloru, AKMB Yayınları, Ankara, 2001, s. VII.

21 Cengiz Badalov, Bütün Yönleriyle Ahıska Türkleri, Çimkent, 2004, s. 26. 
Kuzey Kafkasya'dan sürgün edilen halklarına vatana dönme izni verilir, fakat Ahıska Türklere yurtlarına dönüş hakkı verilmemişti ${ }^{22}$. Yalnızca iki yıl boyunca atalarının yurdunda dönmelerine müsaade olunması için birçok başvuruda bulundular. Gürcü KGB'sinin başı olan Alexei İnauri, toplu dilekçeye: buna müsaade olunmayacağı cevabını verdi. Yani Kırım Tatarları gibi onların da yurtlarına dönmelerine müsaade olunmuyordu ${ }^{23}$.

\section{AHISKA TÜRKLERININ ÖZBEKISTAN-FERGANA BÖLGESINDEKI HAYATI}

Yukarıda bahsettiğimiz gibi, Ahıska Türklerinin anayurdu, Gürcistan'ın Türkiye'ye mücavir sınır bölgesidir. 1944'te Stalin, Türkiye'ye saldırı hazırlığına başladığında, Kırım Türkleri, Volga Almanları, İnguşlar, Balkarlar, Karaçaylar ve Kalmuklar gibi Ahıska Türklerini de, 1944 Kasım-Aralık aylarında orta Asya'ya sürmüştür. Onlar, Orta Asya Türk Cumhuriyetlerine dağınık bir şeklide yerleştirilmiştir. Özbekistan Cumhuriyeti'ne sürülen Ahıska Türklerinin sayısı 50 bindi. 1989 yılında ülkede yapılan nüfuz sayısına göre bu sayı 106 bine ulaşmıştı ${ }^{24}$. Ahıska Türkleri, Fergana, Kokand, Margilan, Kuvasay ve Taşlak gibi bölgelerde yaşamaktaydılar. Fergana vilayetinde ise 16 binden fazla Ahıska Türkü iskân etmekteydi. Burada Ahıskalılar fabrika ve inşaatlarda işçi olarak, ilçelerde ve köylerde tarımcılık, sebze meyvecilik ve pamuk tarlalarında yoğunluk olarak çalışmışlardı. Ahıskalılarla komşuluk eden ve onları yakından tanıyanlar, Türklerin ne kadar çok çalışkan ve dürüst olduklarını teyit etmektedir.

Bunun dışında, Ahıska Türkleri arasında yükseköğrenim alan kişilerin sayısı çok azdı. Çünkü bölgede 1956 yılına kadar insanlar sıkı rejiminden dolayı, komşu köylere bile özel izin almadan gidemiyorlardı ${ }^{25}$. Bu nedenle onların çoğu köy hayatı yaşamaktaydı. Büyüklere saygı tamdı, ayrıca yaşlılar oğulları, gelin ve torunları ile bir arada yaşamışlardı. Bu durum halen dünyanın 9 ülkesinde yaşayan Ahıska Türkleri için geçerlidir. Özbekistan'da uzun süre yaşayan Türkler, Özbekçe ve Rus dillerini konusunda uzmanlaşmıştır. Ayrıca Özbek ve diğer halklardan mutfaklarında çeşitli yemekler yapılmıştır.

Böylece bölgenin iklim ve kültürel şartlarına zamanla uyum sağlayan Türkler, geldikleri andan itibaren alın teriyle hayatlarını kazanmaya çalışmışlardı. Sürgün edildikleri bölge onlar için yavaş yavaş yeni vatan oluyordu. Çocuklarını okula gönderiyor, eğitimini tamamlıyor, çalışmaya başlıyor ve yeni hayatlar kuruyorlardı. Yalnızca, bunların yanında, Ahıskalıların hakları sürekli taraflarına yapılan hak ihlali: idari önlemler (sıkı rejim, çeşitli kısıtlamalar), asimilasyon (pasaportlarında "milliyet" yazan sırada, Gürcü veya Azeri yazmaları), Sovyetler Birliği Komünist Partisi Üyesi kabul süresinde çeşitli gecikmeler vs. halkın ulusal öz bilinci üzerinde olumsuz bir etki yaratmıştı. Bu nedenle Ahıskalıların toplumda herhangi bir konuma ulaşmak için, diğer milletlere nazaran daha da fazla çalışmak ve emek vermeleri gerekiyordu. Sonuç olarak, çok çalışıp iyi bahçeli evlere, araba, hayvanlara, sahip olmuşlardı. Ambarlarında daima un, pirinç ve şeker gibi erzakları hiç eksik olmazdı. Fergana olaylarında bu durumu kullanıp, yerli halkı kışkırtmışlar, Ahıska Türklerini, Özbekleri soyup soğana çeviren, bu nedenle çabuk zenginleşen hırsızlar olarak göstermeye çalışmışlardı26. Oysa Ahıska Türklerinin çoğu köylülerdi. Özbekistan iklim şartlarında yetişen tüm meyve sebzeleri ekip mahsullerini de girişken oldukları

22 Viktor Aksenyev, "Etniçeskiye Konflikt", Konflitologiya, Sankt-Peterburg, 2014, s. 304-321.

23 Nikolay Bugay, "Problemı Vozvraşeniya "Planovıh Pereselentsev" v Rayonı Prejnego Projivaniya do 1940-h gg.", Vestnik Kalmıtskogo instituta Gumanitarnı issledovaniy RAN, V. 4, 2015, s. 50-52.

24 Dalhat Ediyev, Demografiçeskiye Poteri Deportirovannıh Narodov SSSR, Stavropol, 2003. s. 265.

25 Arif Yunusov, Meshetinskiye Turki: Dvajdı Departirovannıy Narod, Baku, 2000, s. 12.

26 Venaliy Amelin, Konflikt Çerez Prizmu Mestnıh Soobşestv: Nauçno-Publitsistiçeskiye Oçerki, İzd. "OGAU”, Orenburg, 2010, s. 12-16. 
için piyasada satıp, geçinmişlerdi. Böylece büyük ailelerinin rahatça yaşayabilmelerini sağlamışlardı, bu da yerli halkın kendilerini kıskanmasına neden olmuştu.

\section{1989-FERGANA OLAYLARI}

1985 yılında SSCB'de iktidarın başına Gorbaçov'un gelmişti. Gorbaçov, Sovyet toplumunda derin gelişme sürecinden kaynaklanan acil bir değişimin gerektiğine inanıyordu. Bu değişimin başlamasındaki gecikme yakın gelecekte ülkede zor bir durum yaratacaktı. Bu da ciddi sosyal, ekonomik ve politik bir buhrana yol açacaktı. Dolayısıyla bir kısım geniş çaplı reform yapılması gerekmekteydi ${ }^{27}$. İkincisiyse perestroyka Gorbaçov reformlarla ülkeye yeni bir güç ve dinamizm vermek isterken, aksine Sovyet sisteminin gerek içerideki gerekse de dünya kuvvet dengesindeki bütün "zaaflarını" açığa vurdu ve iktidarının dördüncü yılı tamamlandığında SSCB içerisinde ihtilaller ve şiddetli etnik çekişmeler başladı. Bu etnik çatışmalardan biri de Özbekistan'ın Fergana vilayetinde yaşanmıştır ${ }^{28}$.

Fergana faciası ile ilgili olarak ilk önce nedenlerin ortaya koyulması gereksinimi duyulmaktadır. illk olarak şunu belirtmek gerekir ki, Ahıska Türkleri SSCB döneminin tamamında Türklüklerini koruyan ve bunu isimlerinde bile gösteren bir topluluk olarak tarihe geçmiştir. 1960’larda başlayan vatanlarına geri dönüş mücadelesi, 1970'lerin ortalarında artık resmiyete dökülmeye başlanmıştı. BM'ye ve Moskova'daki Türkiye Büyükelçiliği'ne yapılan müracaatlar ve mektuplar Sovyet yönetimini tedirgin etmekteydi. Artık 1989 yılının başında bu mücadeleler doruk noktasına ulaşmıştı. Moskova ve Gürcistan SSC bu mesele ile ilgili acilen çözüm zorunluluğunu hissetmiştiler. Hatta 1988'de Sovyet medyasında bu konu ile ilgili bazı programlar yapılmış, bu mesele Ahıska Türklerinin kendi vatanlarına dönmesi üzerinde durulması ile bitmişti. Böylece Ahıska Türklerinin vatana dönüşü yolunda yeni arayışlar başlamış ve bu yönde gelişmelerin önü açılmıştı. Bu durum karşısında ise Ahıska Türklerinin geri dönüşü karşıtı olan Sovyet yönetimi zor durumda kalmıştı. Lakin Sovyet yönetiminin uluslararası düzeylerdeki imzaladığı anlaşmalar sürgün olunmuş halkın geri dönmesi yolunda adımlar atılmasını gerektiriyordu. Bu nedenle de yeniden yapılanmaya doğru geniş bir adım atan SSCB Komünist Partisi bu durumda kaçış yolu da bulunmamaktayd $\imath^{29}$.

Esasen, Özbekistan'da 45 sene yaşayan Ahıskalılar, anavatan topraklarına ve Türkiye'ye dönme mücadelesinden hiçbir zaman vazgeçmemişlerdi. 1956 yılında, sürgün olan halklara uygulanan sıkı rejimin ortadan kaldırılmasıyla, birçok Ahıska ailesi Gürcistan'a dönmek için bölgeye gidip yerleşmeye çalışmışlardı, ancak göç edenleri tutuklayıp geri çevirmişlerdi. Zamanın geçmesi ile ve Gürcistan'da liderin değişmesiyle ülkeye getirilecek yenilik siyaseti konuşulmaya başlandı, Ahıskalılar için ise anavatan topraklarına dönmek için yeni umut doğuyordu. 8 Aralık 1987'de Gürcistan Bakanlar Kurulu, 600 sayılı kararla, Ahıska Türklerinin anavatan topraklarına taşınmasını kabul etti. 1988 yılında Sovyetler Birliği Komünist Partisi Merkez Komitesinin gözetiminde Ahıskalıların sorunu üzerine bir komisyon kuruldu. 1987-1988 yılında ise, Türklerin evvel de başvurdukları "dilekçe"

27 İbrahim Hasanoğlu, "Ahıska Türkleri: Bitmeyen Bir Göç Hikâyesi”, Türk Dünyası Incelemeleri Dergisi, 16 (1), 2016, s. 7-8.

28 Adil Adnan Öztürk, Necat Çetin, “Fergane (Özbekistan) ve Posof'tan İzmir Torbalı’ya Uzanan Ahıskalı Bazı Ailelerin Göç Hikâyesi”, Tarih ve Günce, Atatürk ve Türkiye Cumhuriyeti Tarihi Dergisi, 1/ 2, Kış-2018, s. 191; Aleksandr Osipov, Çto Takoye Etniçeskaya Diskriminatsiya i Çto Mojno s Ney Sdelat? Nauçnoye Izdaniye-Tsentr "Sova", Moskva, 2012, s. 49.

29 Orkhan Faigov, a.g.t., 2015, s. 59-60. 
kampanyası yeniden canlanmıştı. Merkezi kuruluşlarda sürekli toplantılar düzenlendi ${ }^{30}$. Tüm bürokrasi ve gereken işlemler yoluna girmiş gözüküyordu.

Ancak Rusya, Türklerin Ahıska'ya geri dönmelerine karşıydı. Rejimin çökmekte olduğu 1980 'li yılların sonuna gelirken, Sovyetler Birliğini oluşturan Cumhuriyetler bağımsız bir Devlet olmak istiyorlardı. İlk bağımsızlık kazanan Cumhuriyetlerinden birisi de Gürcistan'dı. Ahıskalıların, Ahıska Topraklarına yerleşmesine sıcak bakmayan Moskova, onların meselesini Gürcistan'a baskı yapmak için alet olarak kullanmaya başladı. Moskova'nın ve KGB'nin bu ince hesapları Ermenilerin de işine yaradı. Bu sıralarda Özbekistan'da çoğu Fergana bölgesinde iskân eden Ahıska Türkleri arasında anavatana dönme faaliyetleri güçlenmiştir ${ }^{31}$.

Bununla beraber, 1986-1989 yıllarında Özbekistan'daki pamuk yetiştirmedeki yolsuzluklar hakkında soruşturma yapmak için Moskova'dan gelen Ermeni asıllı savcı Gıdilyan-Ivanov, binlerce Özbek asıllı insanı tutuklayıp ceza evine göndermiştir. Bu gelişmeler üzerine Özbekistan'da azınlıklara, özellikle Rus ve Ermenilere karşı ayaklanma başladı. Tabii ki, KGB durumu kontrol ediyordu ve gelişmelerden haberdardı. 9 Nisan 1989 'da Tiflis ayaklanmasında Gürcü Milleti Rus ordusuna karşı isyan etti ve çatışmalar çıktı. Kızılordu, Sivil topluma karşı silah kullandı onlarca insan öldürüldü. Bu olayları örtbas etmek için Sovyetler Birliği'nin son Cumhurbaşkanı Gorbaçov Özbekistan Cumhurbaşkanı Kerimov ve KGB ile bir senaryo yazdılar ve uygulamaya başladılar.

1) Gürcistan Devletini zor durumda bırakmak için Ahıska Türklerini kullanmak,

2) Özbekistan'daki pamuk tarımındaki yapılan yolsuzlukları ortadan kaldırmak,

3) Özbekistan'daki azınlıklara karşı isyancı olan ve devleti suçlayan "BíRLik" oluşumunu yok etmek,

4) Özbeklerin Rus düşmanlığını Ahıska Türkleri üzerine yönlendirmek, böylelikle iki Türk toplumunu birbirine düşman etmek ${ }^{32}$.

Yazılan senaryo 1989 yılının bahar aylarına uygulanmaya başlamıştır. Rus devletinin emri altında faaliyet gösteren KGB, kısa süre zarfında Ahıska Türkleri ile Özbeklerin arasını bozmuş, senelerce kardeş̧̧e yaşayan iki halkı birbirine düşürmeyi başarmıştı. İki toplum senelerce dostluk ve barış içinde yaşadıkları için, iki tarafa da gelen tehditler onları hayretler içinde bırakmıştı. Ahıska Türklerinin, seneler sonra, bunca emek vererek kavuştukları huzurları elden alınmıştı. Türklere tehditler savruluyor, işlerinden kovuluyorlardı. Özbek halkının mallarına el koyup çaldıkları da iddia ediliyordu ${ }^{33}$. Ahıskalıların çok çalışıp iyi evlerde ve iyi şartlarda yaşamalarından dolayı böyle bir durum onlara karşı kullanılmıştı. Bir anda bölgede sevilmeyen, hoş görülmeyen düşman bir toplum halini almışlardı. Türklerin yoğun olduğu yerlerde, onların yapmadıkları suçları içeren tablolar ve "Türklere Ölüm" pankartları asılmaya başlanmıştı. Özbek toplumu bu ısrarla yayılan kötü haberlere inanmıyordu, ancak KGB'nin planı istedikleri gibi işliyordu. Bölgede cahil insanlara Ahıskalıların bu kötülükleri yaptıklarını ikna etmeye devam etmişlerdi. Bunlar yetmiyormuş gibi, Ahıska Türklerine, Özbekistan'ı terk etmeleri için süre veriliyordu ${ }^{34}$.

30 Aleksandr Osipov, a.g.e., 1998, s. 104.

31 Aslan Kıyas, Ahıska Türkleri, Ankara, 1995, s. 14

32 ibrahim Agara, a.g.e., 2004, s. 29-30.

33 Amelin Venaliy, a.g.e., 2010, s. 18.

34 İsmail Rafatov, Meshetiya i Meshi, İzdatelstvo “ilim”, Bişkek, 1996, s. 23. 
Bölgede ilk gerginlik, Fergana bölgesinin kuzey batısında yer alan Kuvasay şehrinde başlamıştı. Mayısın 23-24'ünde Özbek ve Türk gençleri arasında ilk çatışma ortaya çıkmışı. Sonuç olarak, 1 kişi öldü, 53 kişi yaralandı ve 32 kişi hastaneye kaldırılmıştı. Olaylar üzerine bölgede soruşturma açılmıştı. Durum kontrol altına alınmış gibi görünse de, bu yalnızca başlangıçtı ${ }^{35}$. 1989 senesinin 3-4 Haziran günlerinden itibaren bölgede 1420 yaşındaki gençlere uyuşturucu ve bol miktarda alkol verilerek, Ahıskalıların evlerine kırmızı işaret konuldu. Çok sayıda milliyetçi, bıçak, balta ve metal çubuklarla donatılarak Türklerin yaşadıkları evlere yöneldiler. 3 bine yakın kişi karşılarına çıkan her şeyi talan ederek Türklerin evlerini ateşe vermeye başlamıştır. Bu evlerin yakılmasını emredildi, karşılık verenlerin öldürülmesi istendi. Bundan sonra Türklerin yaşadıkları tüm sokaklara ayrılan insanlar oraya yöneldiler. Fergana'dan gelen polis ve savcının konuşmalarına kimse aldırmadı, talan ve yağma devam etmişti ${ }^{36}$.

Bölgede olaylara tanık olan gazeteciler Max Lurye ve Pyotr Studenikin, durumu şöyle izah etmişlerdi: "Yağma devam etti. Türklerin evleri önce soyuldu, insanlarla alay edildi ve sonra yanan meşaleler ve yangın çıkaran şişeler pencerelere atıldı. Camiden yağma eden insanlara seslenen molla tehdit edilip, susturuldu. Aklını yitirmiş kalabalığın sokaklarda yarattığı korkunç olaylar devam ederken, bazı görevliler Türklerin ailelerini ilçe komitesi binasına nakletmeye çalışmışlardı"37.

Fergana olayları böylelikle başlamış oldu ve çok hızlı şekilde Margila, Taşlak ve Kuvasay şehirlerinde tam ayaklanma halini almıştır. Köy köy gezen insanlar, Ahıska Türklerinin Özbek halkına işkence yaptıklarını söyleyip, durumu daha da kötü hale getirmişlerdi. íki hafta süren kaosun bilançosu, yüzlerce ölü ve yaralıdan ibaret değildir. Ahıska Türkleri, Sovyet Güvenlik Kuvvetleri tarafından kurulan kamplara yerleştirilmiş, büyük bir kısmı da komşu ülke Kazakistan'a, Türkmenistan'a ve Azerbaycan'a kaçmıştır ${ }^{38}$.

Rus basınına göre, Rus yönetimi Fergana'daki olaylara oldukça hızlı hâkim olup, insanlar zarar görmesin diye önce Taşkent'e nakledip, sonra ise Rusya'nın çeşitli bölgelerine uçaklarla göndermişlerdi. Böylece, toplam 16.282 kişinin hayatta kalmasını sağlamışlardı ${ }^{39}$. Oysa İçişleri Bakanlığı (MVD) bölgedeki huzursuzluğu durdurmak için nedense 4 Haziran'ın saat 20:00'ı bekleyerek öyle devreye girmişler ve 5 Haziran'ın sabahında Rus askerlerin sayısı 5 binden 6 bine kadar çıkmıştı. Ancak Rus İçişleri'nin bu olaylara üç günlük gecikmeyle müdahale etmesinin nedeni gizli kalmış ve seneler geçmesine rağmen bu konuda halen mantıklı bir açıklama yapılmamıştır. Binden fazla evin yakılması, 300'den fazla günahsız insanın ölümü, binlerce kadına, çocuğa ve yaşlıya yapılan işkenceler ile sonuçlanan bu dehşet verici olaylar Fergana bölgesindeki 20 bin, Özbekistan'da 100 bine yakın insanın 45 senelik birikimini yok etmişti. Alın teri ile kuruş kuruş biriktirip yaptıkları evler yakıldı yağmalandı. Mal, mülk, bağ, bahçe, her şeylerini kaybettiler ${ }^{40}$.

Ahıska Türkleri, canlarını kurtarmak, kendilerine bir yuva bir ev edinmek için Özbekistan'ı terk etmek zorunda kaldılar. Merkezi Moskova'da olan basın ve haber kaynakları Rus askerlerini Ahıska Türkeri'nin kurtarıcısı olarak gösterdiler. Onlara göre, Kızılordu olmasaydı, Ahıskalıların tamamı öldürülecekti. Böylelikle KGB tereyağından kıl çeker gibi işin içinden sıyrılmış oldu. Askeri uçaklar ile Rusya'nın Kursk, Belgorod, Tula,

35 Aleksandr Osipov, a.g.e., 2014, s. 89-90.

36 Ardayev, B., Fergana: Povtoreniye Proydennogo, BBC, Moskva, 2005.

37 Leonid Lurye, Mihail Studenikin, Zapah Gari i Gorya, Fergana, Trevojnoıy Iyun 1989-go, Moskva, 1990, s.4-5.

38 Amelin Venaliy, a.g.e., s. 17.

39 Leonid Lurye, Mihail Studenikin, a.g.e., 1990, s. 5.

40 ibrahim Agara, a.g.e., 2004, s. 30-32. 
Smolensk vilayetlerine 70-80 Rus ailesi içine 3-5 Türk ailesi yerleştirildi. Rusya Devleti'nin özellikle bu beş vilayeti seçmesi, önceden hazırlamıştı. Yerli halkın: "Siz geçen sene gelecektiniz, neden böyle geç kaldınız", demeleri, senaryonun eskiden yazıldığını ortaya koymaktadır Olayları KGB'nin çok uzun süredir hazırladığı ve başarı ile sonuçlandırdığı görülmektedir. Son olarak Ocak 1990'da Özbekistan'ın başkenti Taşkent'te Ahıska Türklerine yapılan toplantıda: "Biz sizlere güvence veremiyoruz, Özbekistan'ı terk edin", denmesi ${ }^{41}$, Özbek Devletinin de bu senaryo içinde yer aldığını açıkça göstermektedir.

Sovyetler Birliği Komünist Partisi Merkez Komitesi'nin basına açıkladığı rapora göre; Fergana'daki olaylar sonucunda 103 kişi ölmüş, 1011 kişi yaralanmış, 757 konut ve 27 devlet binası yakılmış ve yağmalanmıştır ${ }^{42}$. Bu açıklama ve olaylar, Ahıska Türkleri ile beraber, çeşitli milletlerden temsilcilerin de göçünü tetiklemişti. Fergana olaylarından hemen sonra birkaç gün içerisinde bölgeyi 21 bine yakın kişi terk etmişti. Bunların arasında 16.282 Ahıska Türkü, 1268 Kırım Tatarı, 833 Rus, 310 Tacik, 113 Yahudi, 98 Kırgız, 80 Ermeni, 79 Azerbaycanlı ve 2 bine yakın kişi diğer milletlerdendi ${ }^{43}$. Yalnızca bu sayılar, ilçe göç dairesindeki kayıtlara göre elde edilmişti, aslında, göç eden insan sayısı üç kat daha fazlaydı.

Fergana olayları neticesinde hem Rus iktidarı hem Özbekistan Cumhuriyeti birtakım kazançlar elde etmişti. Kayıtlara göre, Fergana'da nüfusun yoğun olduğu bölgede 20 bin insanın buradan göç etmesiyle, boş bırakılan evlere ve iş yerlerine, bu zamana dek ev ve toprak sorunu olan yerli Özbek halkın yerleşmesiyle devletin milleti ile barışması sağlandı ${ }^{44}$. Ülkede pamuk tarımında yapılan yolsuzluklar bu olaylar ortaya çıkınca herkes tarafından bir anda unutulup kapatıldı. Ayrıca, daha evvel kurulan milliyetçi "BİRLiK" Partisi, bu bahaneyle kapatıldı, yetkili parti üyeleri ise tutuklanıp ceza evlerine gönderildi. Göründüğü gibi, Özbekistan durumu kendi lehine döndürmeye başarmıştı. Ahıska Türklerinin düşüncesine göre, Rusya'nın da, bu olaylardaki çıkar payı küçümsenmez. Asıl, Özbekistan'daki az sayıda olan Rusların Özbekler tarafından yaptırılacak mecburi göçleri durdurulmuştu. Rusya'nın çeşitli bölgelerinde, terkedilmiş köylerine, Ahıska Türklerini nsan gücü olarak kullanarak, tarıma yararlı topraklarda tarım ve hayvancılık yapmalarını sağlayıp, ucuz mahsul yetiştirip, büyük şehirlerde yaşayan Rus halkının geçimini sağlamışlardı ${ }^{45}$. Bununla beraber, diline dinine düşkün olan Ahıska Türklerini Ruslar içine yerleştirip asimile edip, Türk sorununu ortadan kaldırmak istemişlerdi. Söz ettiğimiz olayda kaybeden yalnızca Ahıska Türkleri oldu.

Rus basını bu zamana dek, bu olayları hep farklı yorumlamaya çalışmıştır. Çeşitli hipotezler yürütülmüş, eserler yazılmış, programlar yapılmıştır. Halkın ikinci kez sürgün edilmesi, bu haksızlığa karşı seslerinin daha da yüksek çıkarmalarına neden olmuştur. 1991 yılında "VATAN" cemiyeti, Fergana olayları ile ilgili "Ahıska Türklerine Temyiz" adlı bir açıklama yapmıştı: "Halkımız Sovyetler için yalnızca yeni toprakları işlemek için

41 Aleksandr Osipov, Ferganskaya Dolina Etniçnost, Etniçekiye Protsessı, Etniçeskiye Konflikt, "Nauka”, Moskva, 2014, s. 71-78.

42 TSK Kompartii Uzbekistana "O Targiçeskih Sobıtiyah v Ferganskoy Oblasti i Otvestvennosti Partiynıh, Sovetskih i Pravohranitelnıh Organov", Izvestiya TSK KPSS, N10, 1989, s. 95.

43 Amelin Venaliy, a.g.e., 2010, s. 19-21; 1989 yılı Fergana olaylarından sonra, genç bir grup Ermeni ve Azeri Yahudilerinin yaşadıkları mahalleyi talan etmiş, ölü vakası görülmemişti. 1990 yılı Şubat ayında, Duşanbe Ermeni ve Rus halkı saldırıya uğramışlardı. 1990 yılı 30 Kasımda, Namagan şehrinde kalabalık bir grup tarafından 5 asker öldürülmüştü. Bu etnik çatışmalar, Fergana olayların bir uzantısı ve etkisi olarak kabul edilmiştir. Bkz: Olga Brusina, Aleksandr Osipov, "Mejnatsionalnıye Otnoşeniya: Vzglyad na Problemı Uzbekistana”, Etnografiçeskoye Oformleniye, № 1, 1993, s. 19.

44 Myalo Gonçarov, "Zarevo Ferganı", Novoye Vremya, N37, 8 Sentyabrya, 1989, s. 31.

45 Ibrahim Agara, a.g.e., 2004, s. 33. 
bir köledir. 1944'te Stalin halkımızdan her şeyini alarak, Orta Asya'ya getirip pamuk ve pirinç tarlalarında çalışmaya zorladı. Şimdiki hükümet ise, aynı şekilde, fakat bu sefer kanlı bir senaryo ile halkımızı Rus Federasyonu'nun terk edilmiş topraklarını geliştirmek için sürgün etti". Aynı sene 3 Haziran'da Gence'de (Azerbaycan) Fergana olaylarının ikinci yıldönümünde gerçekleşen mitingin kararında: "Merkezi yetkililerin zımni onayı ile Özbekistan devleti bürokratik aparatı daha evvel hazırlanmış şiddeti gerçekleştirdi, bu da halkımızın kanlı bir trajedisine dönüştü... Bugün, ikinci zorlu göçün kimin tarafından yapıldı̆̆ı bir sır değildir. Bunlar, bazı devlet yetkileridir, onlar bu sefer kanlı bir şekilde, 45 sene boyunca halkımızın anavatan topraklarına dönmelerini engelleyen birileridir"46.

Genel olarak, Fergana olayları, Ahıska Türklerinin vatana dönüş hareketine yeni nitelik eklemişti. Yaşanan etnik çatışmanın sonucunda, Ahıskalılarda bu sorunun kökten çözülmesi konusunda daha sert tepkiler yaratmıştı. Sovyetler de Yüksek Sovyetler Birliği'nin özel komisyonunu "Ahıska Türklerinin anavatana dönme isteklerini yerine getirme olasılığını araştırmak için" oluşturmuşlardır. Komisyon: "Fergana olaylarında Ahıska Türklerinin yaşanan maddi, manevi kayıplarını ve diğer yardımları Özbekistan hükümeti tarafından karşılanmalı" kararını alsa da, söz edilen hükümetin bu yönde kesin adımlar atılmamışı ${ }^{47}$. Yalnızca, Özbek hükümetinin yakılmış Ahıska Türklerinin evleri için ayrılan az bir bütçe, tazminat olarak kabul edilemezdi, çünkü Ahıskalılar ülkeyi terk etmeye devam etmiştir.

\section{AHISKA TÜRKLERININ FERGANA OLAYLARINDAN SONRAKI DURUMLARI}

Fergana olaylarının, Özbekistan dışındaki Orta Asya cumhuriyetlerinde de, örneğin Kazakistan'da ve Kırgızistan'da yaşayan Ahıska Türklerine de yansıdığı, Ahıska Türklerinin bazı bölgelerde, yaşadıkları ülkelerin titüler halklarının tehdit ve baskılarına maruz kaldıkları, hatta tarlalarda saklandıkları ve can kayıplarının olduğu bir gerçektir ${ }^{48}$. Bu olaylar binlerce insanı etkilemiş, 100 bine yakın Ahıska Türkü yeni bir göç yaşamıştı ${ }^{49}$. Rusya'nın "kurtarma" veya "yardım" operasyonu neticesinde, birçok Ahıska Türkü, Rusya'nın çeşitli bölgelerine, gönderilmişti. Ağırlıklı olarak da Kursk, Orel, Smolensk, Tula ve Belgorod gibi yerlere yerleştirmişlerdi. Yalnızca, kısa zaman içerisinde farklı nedenlerden dolayı yeni yerlere alışamayan Ahıskalıların bir kısmı Krasnodar ve Rostov bölgelerine göç etmiştir $^{50}$. Bunun dışında, Fergana olaylarından sonra Özbekistan'da kalmak istemeyen Ahıskalılar Çeçenistan, İnguşetya, Kabardey-Balkar ve Karaçay-Çerkes Cumhuriyetlerine göç etmişlerdi. Ancak Türklerin bu bölgelere göç ettikleri yıllarda, Kuzey Kafkasya'da ve özellikle 1994-1999 yılında Çeçen-Rus savaşlarının etkisinde kalan Ahıskalılar yeni hayat kurdukları bu bölgelerden de ayrılmak zorunda kalmışlardır ${ }^{51}$.

Kuzey Kafkasya'ya yerleşen Ahıska Türkleri çok çeşitli sorunlarla karşılaşmış olsalar da araştırmacıların dikkatini çeken ve dünya gündemine taşınan en önemli sorun ve ayrımcılıklar Krasnodar bölgesinde yaşanmıştır. Fergana Olayları sonrasında Rusya'ya göçün Sovyet döneminde gerçekleşmiş olması Ahıska Türklerine oturma izninin (Rus. propiska) otomatik olarak verilmesini gerektirirken, Kuzey Kafkasya'daki birçok bölgenin tersine Krasnodar bölgesinde yaşamakta olan Ahıska Türklerine oturma izni verilmemiş 46 Aleksand Osipov, a.g.e., 2004, s. s. 50.

47 Eduard Paneş, Leonid Yermolov, "Meshetinskiye Turki", Voprosı İstorii, № 9-10, 1991, s. $212-217$.

48 Ayşegül Aydıngün, "Ahıska Türkleri: Küresel Dinamikler Işığında Göç, Kimlik ve Ulusötesicilik”, Erzincan Üniversitesi Uluslararası Ahıska Türkleri Sempozyumu (11-13 Mayıs 2017) Erzincan Bildirileri, Cilt. 1, 2017, s. 35 49 Aleksandr Osipov, a.g.m, 1998, s. 106.

50 Svetlana Akkiyeva, a.g.e., 1996, s. 20.

51 Viktor Dyatlov, Sergey Ryazantsev, Stabilnost i Konflikt v Rossiyskom Prigraniçye, Etnopolitiçeskiye protsessı v Sibiri i na Kavkaze v Seredine 2000-h godov, Moskva, 2005, s. 78; Viktoriya Simonenko, Meshetinskiye Turki: Istoriçeskaya Sudba i Problemı Kulturnoy Adaptasii, Krasnodar, 2002, s. 27. 
ve böylece her türlü vatandaşlık hakkından mahrum bırakılmışlardır. Başka bir deyişle, bölgedeki varlıkları hukuken tanınmamış ve bunun bir sonucu olarak da çalışma izni almaları, evliliklerin ve doğan çocukların resmî olarak kayıt edilmesi mümkün olamamıştır. Ayrıca, bölgede yapılan mülakatlarda, Ahıska Türkleri, yerel makamlar ve polis tarafından çeşitli baskılara maruz kaldıklarını, pazarlarda tezgâh açanların rahatsız edildiklerini ve hak etmedikleri cezalara çarptırıldıklarını ifade etmişlerdir ${ }^{52}$.

Bu bağlamda dile getirilmesi gereken önemli bir başka konu da, Kuzey Kafkasya'daki Ahıska Türklerinin önemli bir kısmının Ahıska'ya yakın olmak için bölgeye geldikleri ve bölgedeki çatışmalar ve Krasnodar'da propiska alamamaları nedeniyle birçok kez Kuzey Kafkasya'nın farklı yerlerine göç etmek zorunda kaldıklarıdır ${ }^{53}$. Görüldüğü gibi Rus devleti kucak açmış gibi göründüğü halde, birkaç ay sonra Ahıskalıların, Rusya'yı şiddetle terk etmeleri isteniyordu. Rusya'dan sonra Azerbaycan'a yerleşen Ahıskalıların birçoğu, Ermenilere karşı savaşa gönderildiler ${ }^{54}$. Bütün bu olanlardan sonra, Rusya Ahıska Türklerini kamuoyuna Meshet Türkleri olarak tanıttı. Şanlı bir geçmişe sahip olan, 1826 'da Rus ordusuna karşı üstünlük elde eden ${ }^{55}$ bu insanların artık ne yapacaklarını nereye gideceklerini her kuruma ve her devletin gerekli makamında dile getirmişlerdi. Sovyetler Birliği Bakanlar Konseyi Başkanı Nikolay Rıjkov, Ahıska Türklerinin iki ay içerisinde vatanlarına dönmelerini sağlayacağına söz vermişti. Ancak, bu sözler yerine getirilmemiştir.

\section{AMERIKA'DA AHISKA TÜRKLERI}

Yukarıda bahsettiğimiz gibi, Özbekistan'dan Krasnodar'a nakledilen Ahıska Türklerinin ilk üç bin kişisine kimlik ve resmi oturum hakkı verilirken; geri kalan büyük kısmına bu hak tanınmamıştır. Bu sebeple Ahıska Türklerinin kahir ekseriyeti Krasnodar'da geçen 15 sene süresince çocuklarına düzenli bir eğitim imkânı sunamamış, emlak satın alamamış, oy kullanamamış, kazandığı hiçbir malın gerçek maliki olamamış, nihayet adeta "kaçak ve kanunsuz" bir hayat yaşamışlardır. Bu durumun onların hayatını ne derece çekilmez kılabileceği takdir edilecektir. Uzun zaman Türkiye'den bir çözüm beklenmiş, 1992 yılında yasal bir düzenleme yapılmış, fakat bu düzenleme hayata istenen ölçüde geçirilememiştir. Ahıska Türkleri son çare olarak durumlarını Amerika'nın Rusya'daki makamlarına iletmişler ve Amerika, Krasnodar'dan 25 bin kadar Ahıskalıyı mülteci statüsünde kabul edeceğini beyan etmiştir. 2005 yılında başlayan programa ancak 12 bin 500 kadar Ahıska Türkü iştirak edebilmiştir. Zira geriye kalan kısmın pasaport çıkarmak için gerekli harcı yatıramadığı bilinmektedir. Bununla beraber, Amerika'ya gidişe kendi içlerinden de muhalefet çıkmıştır. Dolayısıyla maddi imkânı görece olarak yerinde olanlar ve Amerika'ya gitmek isteyenler bu programa başvurmuşlardır. Amerika'ya göç eden yaklaşık 12.500 Ahıskalı Türk nüfus, ortalama 100- 200 hanelik gruplar halinde ülkenin 26 eyaletinde 60 kadar şehre iskân edilmişlerdir. Amerika'daki Ahıskalı nüfus bir mülteci programı kapsamında gelişigüzel dağıtıldığı ve henüz yerleşme aşamasında bulunduğu için son derece hareketli bir nüfustur ${ }^{56}$.

52 Ayşegül Aydıngün, İsmail Aydıngün, Ahıska Türkleri Ulusötesi Bir Topluluk-Ulusötesi Aileler, Hoca Ahmet Yesevi Uluslararası Türk-Kazak Üniversitesi İnceleme-Araştırma Dizisi. 21(1), AnkarA, 2014, s. 105-120.

53 Ayşegül Aydıngün, a.g.m., 35-36; Viktor Dyatlov, Sergey, Ryazantsev, a.g.e., 104-111; Vladimir Karastalev, Reşeniye Problemı Bezgrajdanstva sredi Grajdan Bıvşego SSSR ( Na Primere Programmı Pereseleniy TurokMeshetintsev iz Rossiyskoy Federatsii v SŞA (2004-2008), (Neopublikovannaya Kvalifikatsionnaya Rabota Magistra), Sankt-Peterburg, 2008, s. 14-32; Aleksandr Osipov, "Konstruirovaniye Etniçeskogo Konflikta i Rasistkiy Diskurs", Opublikovanno: Rassizm v Yazıke Sotsialnıh Nauk, İzdatelstvo “Aleteya”, SPb, 2002, s. 1.

54 Cengiz Badalov, a.g.e., 2004, s. 29.

55 Rasim Bayraktar, a.g.e., 2000, s. 46-50.

56 Yavuz M. Alptekin, “Abd-Colorado'da Yaşayan Ahıskalı Türk Topluluğunda Ekonomik, Sosyal ve Kültürel Hayat", Sosyoloji Konferansları, No: 47, 2013, s. 4-10. 
Yaklaşık 200 yıldır sürgün ve yer değiştirme politikalarından ötürü hayatta kalma mücadelesi veren Ahıska Türklerinin Amerika'da görece arzu ettikleri bir ortam içerisinde bulundukları görülmektedir. Ancak kültürün yaşamın her boyutuyla ilişkisi nedeniyle sürgünün izleri hafızalarda taşınmakta ve kendisini kimlikle ilintili formlar içerisinde sıklıkla hissetmektedir. Sürgün bilinci ve gelecekle ilgili kaygılar mevcudiyetini korurken bu durum vatandaşlık hakkı ve yerleşme imkânlarının elde edilmesiyle biraz yumuşamış görünmektedir. Temel sorunsal ise içe dönük sosyal yapıların oluşma tehdididir ve orta yaş kuşağı ve üzerinin dış gruplarla ilişkisi yok denecek kadar azdır ${ }^{57}$.

Görüldüğü gibi, tüm bu olaylar, zorunlu sürgün ve göçler, Ahıska Türklerini çok etkilemiş ve dış dünya ile bağlantı kurmalarını zorlaştırmıştır. Yaşadıkları etnik çatışma ve gördükleri şiddetten kaçarak kendilerini yeni etik-kültürel ortamda bulmuşlardı. Yalnızca Azerbaycan'a giden kısım, kendine yakın olan bir kültürle karşılaşmışlardı. Bunun dışında, eski SSCB cumhuriyetlerine ve diğer ülkelere yerleşen Türkler, karmaşık siyasi süreçlerde yer almışlardı.

Birçok Gürcü bilim adamı ve siyasetçisi Ahıska Türklerine halen Meskhet Türkleri demekte ve onları Müslümanlığı kabul eden Gürcüler olarak kabul etmektedir. Gürcistan devleti ise, anavatan topraklarına dönmek isteyen Ahıska Türklerine, Gürcü soyadlarını aldıkları takdirde, kabul edeceklerini beyan etmişlerdi ${ }^{58}$. Tarihe bakılırsa, ta 1956 yılından bu yana dönemin Sovyet ve Gürcistan devleti, topraklarından haksız yere sürgün edilen Ahıska Türklerinin Ahıska'ya yerleştirilmesine olumlu bakmamış ve çeşitli bahanelerle Ahıskalıların taleplerini reddetmişti. Sovyetler birliği dağıldıktan sonra Gürcistan devletinde büyük değişikler yapıldı. 1999'da, Gürcistan Avrupa Konseyine Üye olunurken, Avrupa Konseyine kabulünden itibaren iki yıl içinde Sovyet rejimi tarafından zorla göç ettirilen Ahıska Türklerinin vatanlarına iadeleri, Avrupa Konseyine girişinden itibaren üç yıl içinde vatana iade ve entegrasyon sürecini başlatmaya ve 12 yıl içinde göçü tamamlamaya söz vermiştir ${ }^{59}$. Avrupa Konseyi, AGiT ve BM Mülteciler Yüksek Komiserliği uzmanlarınca Gürcistan'da hazırlanan ortak raporda Gürcistan'ın bu konudaki çabaları yetersiz bulunmuştur ${ }^{60}$. Söz konusu konseyde 19 sene geçmesine rağmen hiçbir ilerleme ve çalışma kaydedilmedi.

\section{Sonuç}

1989 yılında meydana gelen Fergana olayları, yarattığı şiddetin boyutları ile Rusya'da o zamana dek görülmüş en ağır etnik çatışmaydı. Fergana olaylarından sonra 100 bine yakın Ahıska Türkü bölgeyi terk etti. Ancak bunların yalnızca 16 bini Sovyet hükümetinin kontrolü altında gerçekleşti. Gerçek şu ki 70 bine yakın Ahıska Türkü, olayların etkisinde kalarak, bölgeden kendi isteği ile ayrıldı. Muhtelif bölgelere yerleşen Ahıskalılar, bir süre sonra farklı nedenlerden ötürü göç ettikleri bölgelerden başka yerlere yöneldiler. Bu noktada Ahıskalıların, iskânına dair çalışmaların da 1990 yılından sonra yapıldığı gerçeği ile karşılaşmaktayız. Ancak, SSCB gibi büyük ve dört tarafı kontrol etme gücüne sahip olan bir devletin, çok sayıda masum insanın hayatına mal olan, böylesine elim bir olayın basit bir

57 İbrahim Hasanoğlu, "25. Yıldönümü Münasebetiyle: Ahıska Türklerinin Fergana Faciası”, Bizim Ahıska, Bahar sayısı, 2014, s. 12.

58 Marian Tuhaşvili, Bejentsy i Vınuzhdenno Peremeshennıe Litsa Gruzii, Poyasnitelnaya Zapiska 13/104, 13/104, EUI, RSCAS, 2013, s. 3; Voytseh Guretskiy, “Djavahetskiy Vopros”, Kavkazskiye Regionalnıye İssledovaniya, T. 3, № 1, 1997.

59 ibrahim Agara, a.g.e., 2004, s. 37.

60 Akif Kütükçü, "Uluslararası Hukuk Çerçevesinde Ahıska Türklerinin Anavatanlarına Dönüş Sorunu”, Selçuk Üniversitesi Sosyal Bilimler Dergisi, Yıl: 2015, Sayı: 13, s. 277. 
pazar kavgasından ortaya çıkmasına seyirci kalmış olması, inandırıcılıktan uzaktır. Fergana olaylarının arka planında yatan Sovyet planlarının ne olduğu konusunda kesin bir kanıta sahip olamasak da, bildiğimiz tek şey bu olaylar neticesinde 100 bine yakın insanın göç etmek zorunda kaldığıdır. Üstelik de bir önceki sürgünün yaralarını sarmaya, yeni yeni alıştıkları ikinci vatanlarına adapte olmaya çalıştıkları bir sırada, Ahıskalıların birçoğu bu ikinci facia nedeniyle evlerini, topraklarını ve bazıları da hayatını kaybettiler. 1989 yılından bu güne dek, halen sürgünde yaşayan, kendilerini bir türlü toparlayamayan, çocukları için endişe ederek hayat mücadelesi veren binlerce Ahıskalı aileyi göz ardı edemeyiz. Fergana'da gerçekleşen bu insanlık dışı olayları unutturmak veya onların hafızlarından silmek asla mümkün değildir. Ahıskalılar, gittikleri her yeni ülkede, daima o psikoloji ile yaşamak zorunda kalacaklardır. Hatta bu olayların etkisi Kazakistan, Kırgızistan ve diğer ülkelerde yaşayan Ahıskalıların hafızalarında da derin izler bırakmıştır. Ahıskalılar her ne kadar bu olayın peşini bırakmış gibi görünseler de, aslında istedikleri tek şey, Gürcistan ve Özbekistan'da kendilerine bu zulmü reva gören sorumluların bir gün cezalandırıldıklarını görmektir.

\section{KAYNAKÇA}

AGARA, İbrahim, İnsanlık Dramı, İzmir, 2004

AKKIYEVA, Svetlana, Turki Meshetintsı v KBR: Demografiçeskoye i Etnokulturnoye Razvitiye, Nalçik, 2016.

AKSENYEV, Viktor, "Etniçeskiye Konflikt", Konflitologiya, Sankt-Peterburg, 2014, s. 304321.

ALPTEKIN, M. Yavuz, “Abd-Colorado'da Yaşayan Ahıskalı Türk Topluluğunda Ekonomik, Sosyal ve Kültürel Hayat", Sosyoloji Konferansları, No: 47, (2013-1), s. 1-29.

AMELiN, Venaliy, Konflikt Çerez Prizmu Mestnıh Soobşestv: Nauçno-Publitsistiçeskiye Oçerki, İzd. "OGAU”, Orenburg, 2010.

ARSLAN, Ali, “I. Dünya Savaşı ve Milli Mücadele Döneminde Ahıska-Ahılkelek (1914-1921)”, Kafkas Araştırmaları Dergisi, N3, İstanbul, 1997, s. 98-110.

ARDAYEV, B., Fergana: Povtoreniye Proydennogo, BBC, Moskva, 2005.

AŞHAMAHOVA, Asiyet, Yujnaya Gruziya pod Upravleniyem Rossiyskoy İmperii, s. 1-5.

AYDINGÜN, Ayşegül, AYDINGÜN, İsmail, Ahıska Türkleri Ulusötesi Bir Topluluk-Ulusötesi Aileler, Hoca Ahmet Yesevi Uluslararası Türk-Kazak Üniversitesi İnceleme-Araştrrma Dizisi, Ankara, 2014, s. 105-120.

AYDINGÜN, Ayşegül, “Ahıska Türkleri: Küresel Dinamikler Işığında Göç, Kimlik ve Ulusötesicilik", Erzincan Üniversitesi Uluslararası Ahıska Türkleri Sempozyumu (1113 Mayıs 2017) Erzincan Bildirileri, Cilt. 1, 2017, s. 33-40.

AKKIYEVA, Svetlana, Turki Meshetintsı v KBR: Demografiçeskoye i Etnokulturnoye Razvitiye, Nalçik, 2016.

BADALOV, Cengiz, Bütün Yönleriyle Ahıska Türkleri, İszdatelstvo "Ğasır-Ş”, Çimkent, 2004.

BAYRAKTAR, Rasim, Ahıska-Çıldır Beylerbeyliği, Yaşayan Kitaplar, İstanbul, 2000.

BEZUGOLNIY, Aleksey, BUGAY, Nikolay, YEVGENiY Krinko, Gortsı Severnogo Kavkaza v Velikoy Oteçestvennoy Voyne 1941-1945. Problemı İstorii, İstoriografii i İstoçnikovedeniya, izd. Tsentpoligraf, 2012.

BRUSiNA, Olga, OSiPOV, Aleksandr, "Mejnatsionalnıye Otnoşeniya: Vzglyad na Problemı Uzbekistana", Etnografiçeskoye Oformleniye, № 1, 1993, s. 15-27.

BUGAY, Nikolay, L. Beriya-i. Stalinu "Soglassno vaşemu Ukazaniyu", Moskva, 1994. 
BUGAY, Nikolay, "Problemı Vozvraşeniya "Planovih Pereselentsev" v Rayonı Prejnego Projivaniya do 1940-h gg.", Vestnik Kalmıtskogo İnstituta Gumanitarnıh İssledovaniy RAN, V. 4, 2015, s. 43-53.

DYATLOV, Viktor, RYAZANTSEV, Sergey, Stabilnost i Konflikt v Rossiyskom Prigraniçye, Etnopolitiçeskiye protsessı v Sibiri i na Kavkaze v Seredine 2000-h godov, Moskva, 2005.

EDIYEV, Dalhat, Demografiçeskiye Poteri Deportirovannıh Narodov SSSR, Stavropol, 2003.

FAiGOV, Orkhan, Ahıskalı Türklerin Türk Basınında Sunum Biçimi 1944 Ahıska Sürgünü, 1989 Fergana Faciası, 2004 Krosnodar Göçü ve 2010 Kırgızistan Çatışması Örnek Olayları, (Basılmamış Yüksek Lisans Tezi), Erzurum, 2015.

GONÇAROV, Myalo, "Zarevo Ferganı”, Novoye Vremya, , N37, 8 Sentyabrya, 1989, s. 31-34.

GULBINSKIY, Yuriy, Naçalnıy Period Velikoy Oteçestvennoy Voynı i Deportatsiya Rossiyskih Nemtsev: Vzglyadı i Otsenki Çerez 70 let, Materialı 3-ey Mejduanrodnoy NauçnoPraktiçeskoy Konferentsii, Saratov, 26-28 Avgust 2011, Moskva, 2011.

GURETSKiY, Voytseh, "Djavahetskiy Vopros”, Kavkazskiye Regionalnıye İssledovaniya, Tom. 3, № 1, 1997, C:\Users\Pau\Desktop\Fergana Kaynakça\25. Voytseh\Кавказские Региональные Исследования - Том 3, No 1, 1997.html

HACILI, Asif, POLATOĞU Aydın, Ahıska Türk Folkloru, AKMB Yayınları, Ankara, 2001.

HASANOĞLU, İbrahim, "Ahıska Türkleri: Bitmeyen Bir Göç Hikâyesi", Türk Dünyası İncelemeleri Dergisi, 16 (1), 2016, s. 1-20.

KARASTALEV, Vladimir, Reşeniye Problemı Bezgrajdanstva sredi Grajdan Bıvşego SSSR ( Na Primere Programmı Pereseleniy Turok-Meshetintsev iz Rossiyskoy Federatsii vc SŞA (2004-2008), (Neopublikovannaya Kvalifikatsionnaya Rabota Magistra), SanktPeterburg, 2008.

KIRZIOĞLU, Fahrettin, Dede-Korkut Oğuznameleri, 1. Kitap, İstanbul, 1952.

KIYAS, Aslan, Ahıska Türkleri, Ankara, 1995.

KÜTÜKÇÜ, Akif, “Uluslararası Hukuk Çerçevesinde Ahıska Türklerinin Anavatanlarına Dönüş Sorunu", Selçuk Üniversitesi Sosyal Bilimler Dergisi, Yıl: 2015, Sayı: 13, s. 272-284.

LURYE, Leonid, STUDENIKIN, Mihail, Zapah Gari i Gorya, Fergana, Trevojnoıy İyun 1989-go, Moskva, 1990.

Osipov, Aleksandr, "Dvijeniye Meshetintsev za Repatriatsiyu (1956-1988)", Etnografiçeskoye Obozreniye, № 5, 1998, s. 95-107.

OSiPOV, Aleksandr, "Konstruirovaniye Etniçeskogo konflikta i Rasistkiy Diskurs", Opublikovanno: Rassizm v Yazıke Sotsialnıh Nauk, İzd. "Aleteya", SPb, 2002, s. 1-11.

OSiPOV, Aleksandr, Çto Takoye Etniçeskaya Diskriminatsiya i chto Mojno s ney Sdelat? Nauçnoye İzdaniye-Tsentr "Sova”, Moskva, 2012.

OSiPOV, Aleksandr, Ferganskaya Dolina Etniçnost, Etniçekiye Protsessı, Etniçeskiye Konflikt, "Nauka”, Moskva, 2014.

ÖZTÜRK, Adnan, ÇETIN, Necat, “Fergane (Özbekistan) ve Posof'tan İzmir Torbalı'ya Uzanan Ahıskalı Bazı Ailelerin Göç Hikâyesi”, Tarih ve Günce Atatürk ve Türkiye Cumhuriyeti Tarihi Dergisi, 1/ 2, Kış-2018, s. 187-200.

PANEŞ, Eduard, YERMOLOV, Leonid, "Turki Meshetintsı (İstorikoEtnografiçeskiy Analiz Problemı)", Sovetskaya Etnografiya, № 1, Moskva, 1990, s. 16-25. 
PANEŞ, Eduard, YERMOLOV, Leonid, “Meshetinskiye Turki”, Voprosı İstorii, № 9-10, 1991, s. 212-217.

Polnoye Sobraniye Zakonov Rossiyskoy İmperii, Sobraniye 2-e, T. 4, №3128, SPb, 1830.

POLYAN, Pavel, "Nasistvennıye Migratsii i Geografiya Naseleniya”, Mir Rossii, № 4, 1999, s. $102-113$.

RAFATOV, İsmail, Meshetiya i Meshi, İzdatelstvo “ilim”, Bişkek, 1996.

SIMONENKO, Viktoriya, Meshetinskiye Turki: İstoriçeskaya Sudba i Problemı Kulturnoy Adaptasii, Krasnodar, 2002.

ŞEREMET OV, Vitaliy, Turtsiya i Andrianopolskiy Mir, İzdatelstvo “Nauka”, 1975.

TSK Kompartii Uzbekistana "O Targiçeskih Sobıtiyah v Ferganskoy Oblasti i Otvestvennosti Partiynıh, Sovetskih i Pravohranitelnıh Organov", İzvestiya TSK KPSS, N10, 1989.

TUHAŞVILI, Mirian, Bejentsı i Vınujdenno Peremeşennıe Litsa v Gruzii, Poyasnitelnaya Zapiska 13/104, EUI, RSCAS, 2013, s. 1-5.

YAKOVLEV, Aleksandr, Stalinskiye Deportatsii. 1928-1953, (Rossiya. XX. vek. Dokument), İzd. Materik, Moskva, 2005.

ZEYREK, Yunus, Ahıska Gül İdi Gitti, Ankara, 2015.

YUNUSOV, Arif, Meshetinskiye Turki: D vajdı Departirovannıy Narod, Baku, 2000. 


\section{EKLER}

Ek I: Ahıska Türklerinin Fergana bölgesindeki yakılmış evleri.

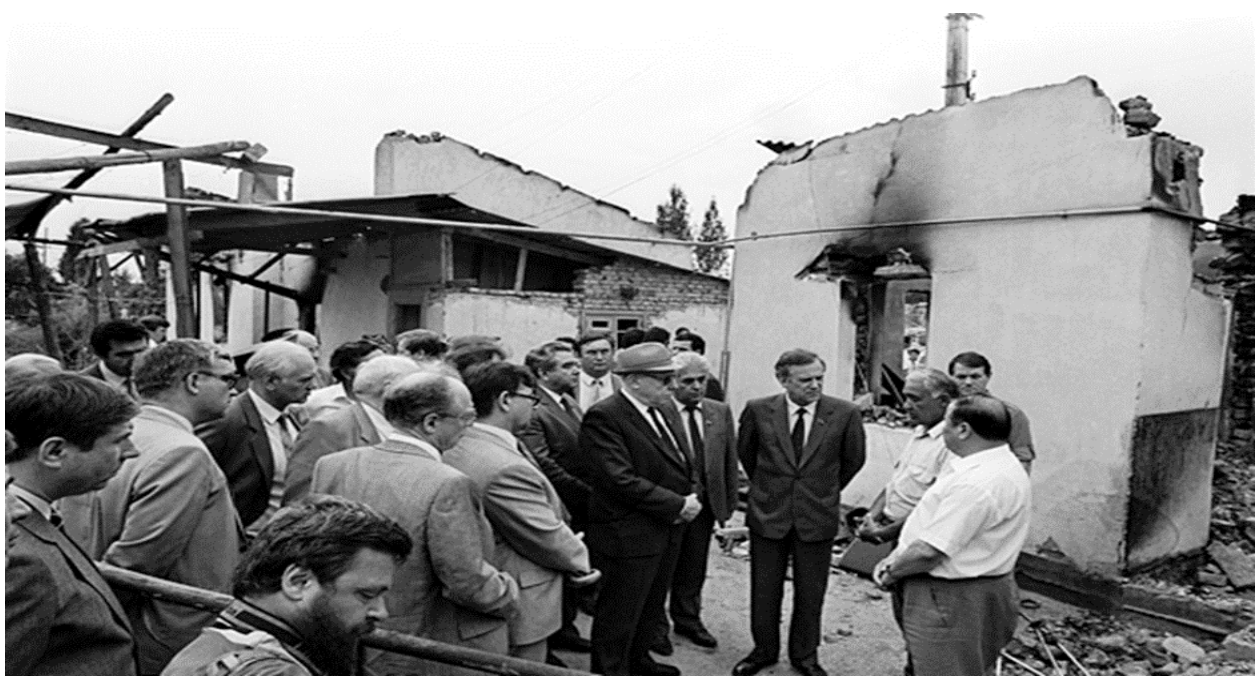

http://rusplt.ru/society/nikolay-ryijkov-i-ferganskie-pogromyi-1989-goda-12256.html

Ek: II: 1989 yıl, Ahıska Türkleri Fergana olaylarının kurbanlarını toprağa verirken.

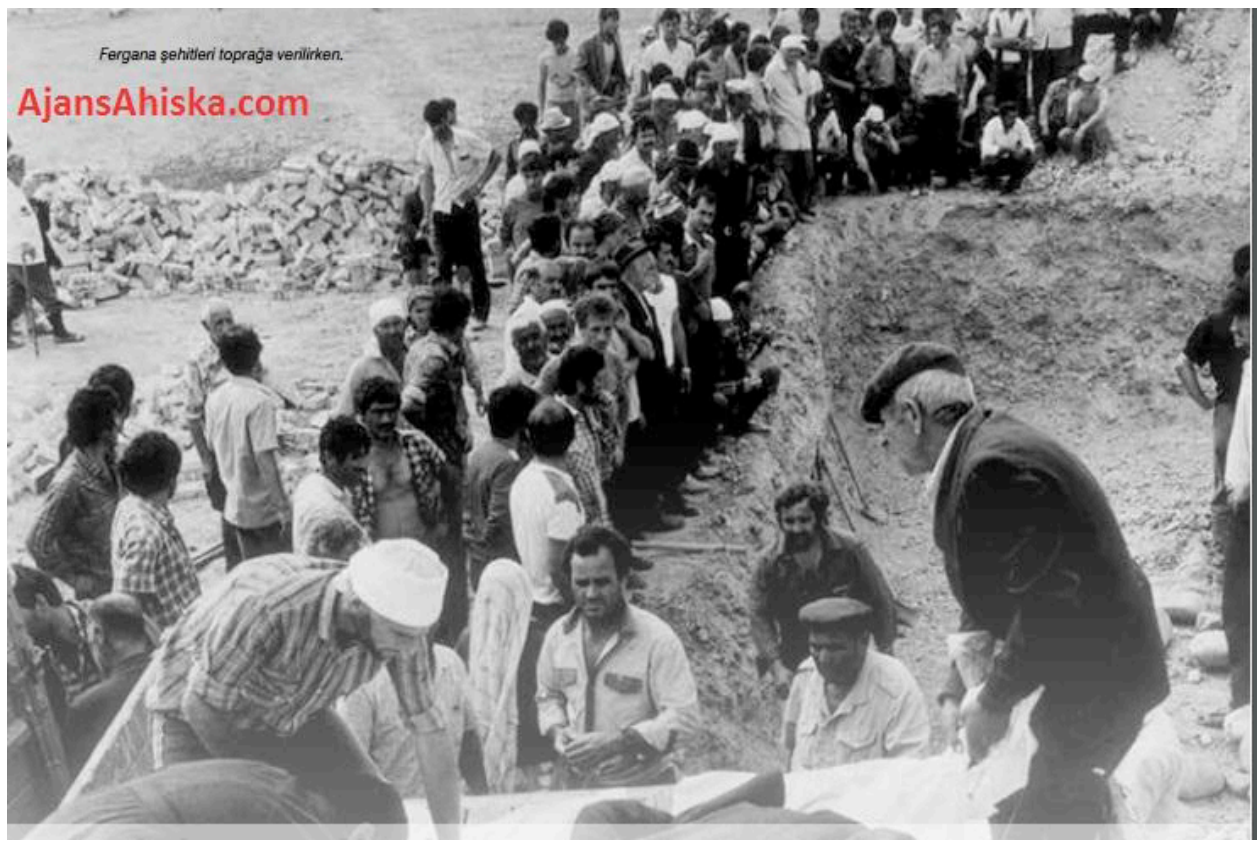

http://www.ajansahiska.com/haber/ferganadan-feryatlar_h412.html 
Ek:III: 1989 yıl, Özbekistan'daki Ahıska Türkleri. Fergana bölgesinin askeri alanında Rusya'ya gönderilmeyi beklerken.

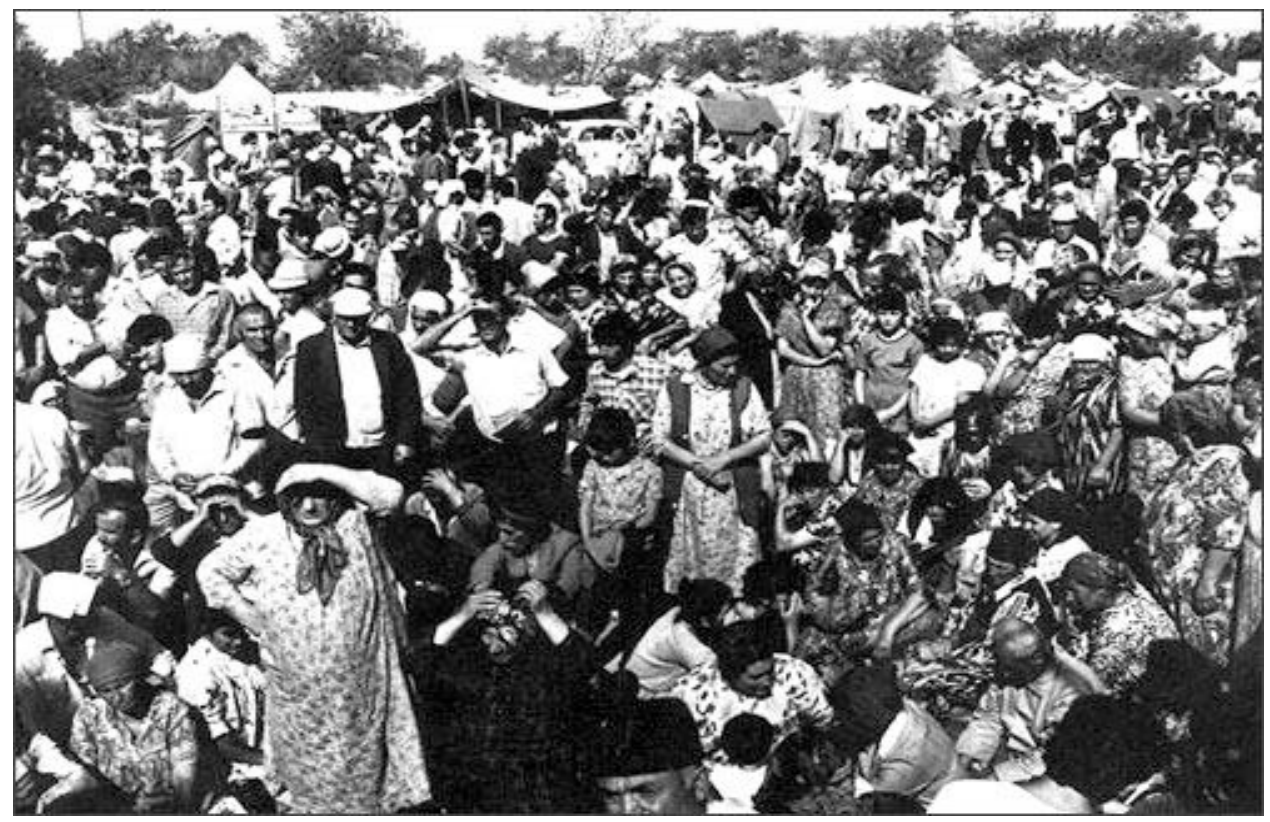

https://www.gzt.com/mecra/noktasiz-hikaye-ahiska-surgunu-3463632

Ek: IV: 1989 yıl, Özbekistan'daki Ahıska Türkleri. Fergana bölgesinin askeri alanı.

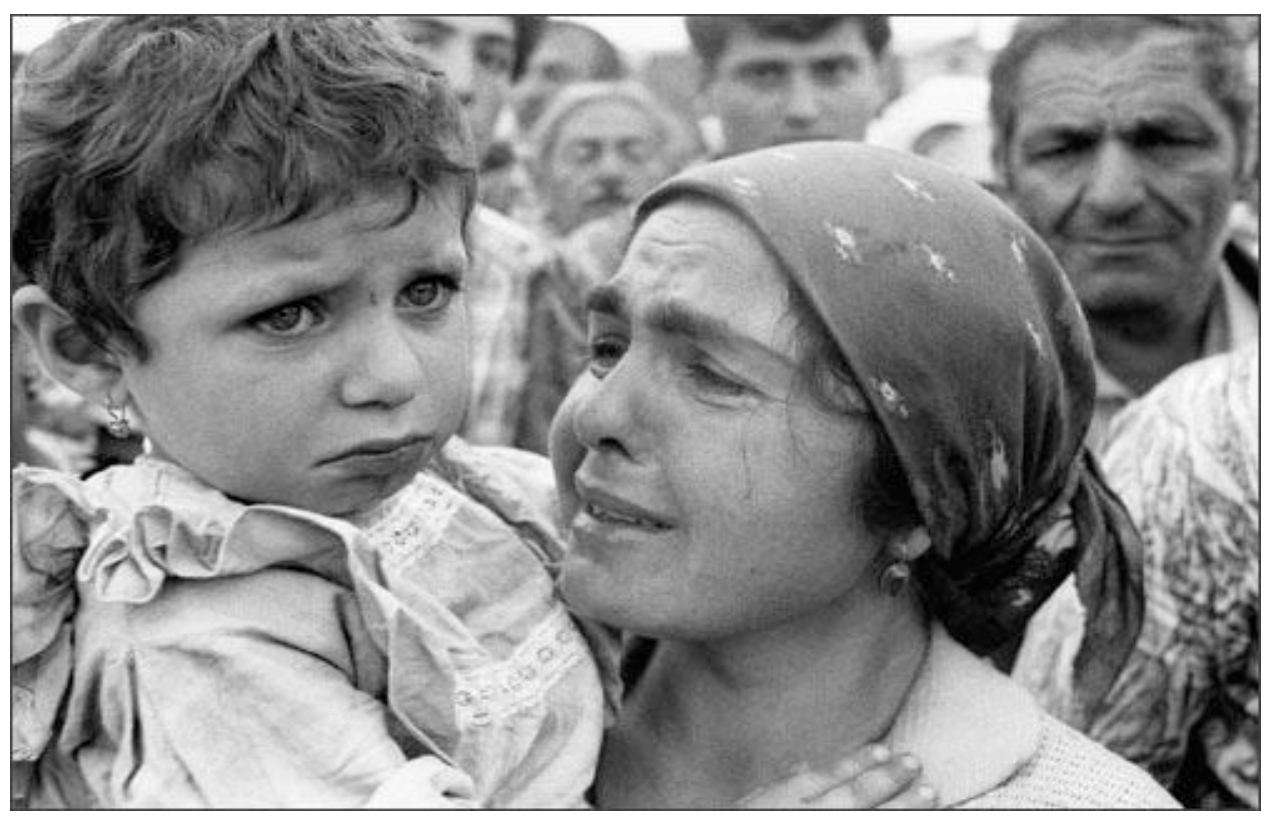

https://www.gzt.com/mecra/noktasiz-hikaye-ahiska-surgunu-3463632 